\title{
HUBUNGAN AKTIVITAS SEKSUAL PADA USIA DINI, PROMISKUITAS DAN BILAS VAGINA DENGAN KEJADIAN KANKER LEHER RAHIM PADA PASIEN ONKOLOGY DI RSUD Dr.MOEWARDI SURAKARTA
}

\author{
Ridhaningsih, Sitti Nur Djannah \\ Fakultas Kesehatan Masyarakat, Universitas Ahmad Dahlan, Yogyakarta
}

\begin{abstract}
Background: Cervical cancer ranks the top cause of cancer deaths in developing countries. At Dr. Moewardi Hospital Surakarta cervical cancer was found in most cancers. Risk factors associated with health and cleanliness of the female reproductive tract can increase the incidence of cervical cancer. Purpose this study aims to determine factors associated with female reproductive health tract and the occurrence of cervical cancer.

Method: The study was a quantitative analytical research used cross sectional design. Data used primary data from interviews and secondary data from medical records. Bivariate analysis using chi square test used to prove the hypothesis.

Results: Statistical analysis by chi square test for sex at an early age got $p$ value $=0,382$ and the prevalence ratio $=1,375$, for promiscuity with incidence cervical cancer got $p$ value $=0,481$ and prevalence ratio $=1,314$, for vaginal douching with incidence cervical cancer got $p$ value $=0,121$ and prevalence ratio $=0,571$.

Conclusion: There was no significant correlation between sex on early age with incidence of cervical cancer, there was no significant correlation between promiscuity with incidence of cervical cancer, there was no significant correlation between vaginal douching with incidence of cervical cancer at Dr. Moewardi Hospital Surakarta on Mey until Juny 2010.
\end{abstract}

Key words: sex at an early age, promiscuity, rinse the vagina, cervix cancer

\section{PENDAHULUAN}

Kanker leher rahim sampai saat ini, masih merupakan masalah kesehatan perempuan di Indonesia sehubungan dengan angka kejadian dan angka kematian yang tinggi. Keterlambatan diagnosis pada stadium lanjut, keadaan umum yang lemah, status sosial yang rendah, keterbatasan sumber daya, keterbatasan sarana dan prasarana dan derajat pendidikan ikut serta dalam menentukan prognosis dari penderita. $^{1}$

Beberapa faktor yang diduga meningkatkan kejadian kanker leher rahim yaitu faktor sosiodemografis yang meliputi usia, status sosial ekonomi, dan faktor aktivitas seksual yang meliputi usia pertama kali melakukan hubungan seks, pasangan seks yang berganti-ganti, paritas, kebersihan genital, merokok, riwayat penyakit kelamin, trauma kronis pada serviks, serta penggunaan kontrasepsi oral dalam jangka lama yaitu lebih dari 4 tahun. ${ }^{2}$

Usaha untuk menjaga kebersihan genital bisa dilakukan dengan tindakan bilas vagina. Banyak kaum wanita melakukan bilas vagina terutama setelah menstruasi atau setelah berhubungan seksual dengan tujuan menjaga kebersihan. Penelitian di Amerika membuktikan bahwa perempuan yang secara rutin melakukan bilas vagina lebih besar kemungkinan terkena masalah kesehatan daripada perempuan yang tidak rutin melakukannya. Tindakan bilas vagina juga akan mendorong mikro organisme di vagina dan leher rahim masuk ke dalam rongga rahim, saluran telur dan indung telur. ${ }^{3}$ 


\section{METODE PENELITIAN}

Jenis penelitian ini merupakan penelitian analitik kuantitatif dengan menggunakan rancangan cross sectional. Lokasi penelitian adalah RSUD Dr. Moewardi Surakarta. Subjek penelitian adalah seluruh pasien onkology yang menjalani rawat inap pada bulan Mei-Juni 2010 yang berjumlah 50 orang. Instrumen penelitian yang digunakan dalam penelitian ini adalah data primer yang diperoleh dari wawancara dan data sekunder. Analisis data dilakukan melalui 2 tahap yaitu analisis univariat dan bivariat.

\section{HASIL PENELITIAN DAN PEMBAHASAN}

\section{a. Hasil Penelitian}

1) Gambaran Umum Lokasi Penelitian

RSUD Dr. Moewardi Surakarta adalah gabungan dari tiga Rumah Sakit "Pusat" Surakarta (Mangkubumen), Rumah Sakit "Surakarta" (Jebres), Rumah Sakit "Kadipolo" (Kadipolo). Pada tahun 1996 menempati gedung baru di Jebres dan tahun 1999 menjadi Rumah Sakit Unit Swadaya. RSUD Dr. Moewardi Surakarta adalah milik pemerintah Propinsi Jawa Tengah, Tipe B Pendidikan. Merupakan rumah sakit rujukan (untuk wilayah Jawa Tengah bagian Selatan dan Jawa Timur bagina Barat) dan sekaligus sebagai rumah sakit pendidikan utama Fakultas Kedokteran Universitas Negeri Surakarta.

RSUD Dr. Moewardi Surakarta adalah rumah sakit yang memberikan pelayanan kesehatan dengan mutu yang setinggi-tingginya dan melaksanakan fungsi pendidikan kesehatan di rumah sakit dengan sebaikbaiknya yang diabdikan bagi kepentingan derajat kesehatan masyarakat. Visi dan misi Menjadi Rumah Sakit Pilihan Utama Masyarakat Jawa Tengah 2010. Menyelenggarakan pelayanan kesehatan yang bermutu prima dan memuaskan. Memberikan pelayanan yang terjangkau bagi semua golongan masyarakat. Memberikan kontribusi nyata untuk pendidikan dan penelitian kesehatan yang terintegrasi dengan pelayanan dalam rangka peningkatan mutu SDM dan Iptek kesehatan. Tujuan didirikannya rumah sakit adalah Kemandirian Finansial Rumah Sakit, Kepuasan Pelanggan, Proses Pelayanan yang Prima, SDM Berkomitmen Tinggi dan Kompeten

\section{2) Analisis Univariat}

Analisis univariat bertujuan untuk menggambarkan distribusi, persentase responden dan dapat mendeskripsikan tiap-tiap variabel dengan tabel.

a) Distribusi Responden Berdasarkan Seks Pada Usia Dini

Tabel 1. Distribusi Responden Berdasarkan Seks pada Usia Dini Pada Pasien Onkology RSUD Dr. Moewardi Surakarta bulan Mei-Juni 2010

\begin{tabular}{|c|c|c|c|}
\hline No & Seks Usia Dini & Frekuensi & Persentase \\
\hline 1. & Ya & 25 & 50 \\
\hline 2. & Tidak & 25 & 50 \\
\hline & Total & 50 & 100 \\
\hline
\end{tabular}


Berdasarkan tabel 1 didapatkan hasil bahwa jumlah responden yang melakukan aktivitas seksual pada usia dini dan yang tidak melakukan hubungan seksual pada usia dini adalah seimbang yaitu $50 \%$ melakukan, $50 \%$ tidak melakukan.

b) Distribusi Responden Berdasarkan Promiskuitas

Tabel 2. Distribusi Responden Berdasarkan Aktivitas Promiskuitas pada Pasien Onkology RSUD Dr. Moewardi Surakarta bulan Mei-Juni 2010

\begin{tabular}{|c|c|c|c|}
\hline No & Promiskuitas & Frekuensi & Persentase \\
\hline 1. & Ya & 13 & 26 \\
\hline 2. & Tidak & 37 & 74 \\
\hline & Total & 50 & 100 \\
\hline
\end{tabular}

Berdasarkan tabel 2 didapatkan hasil yang menunjukkan bahwa kebanyakan responden tidak melakukan aktivitas promiskuitas yaitu sebanyak 37 responden (74\%), sedangkan yang melakukan aktivitas promiskuitas adalah sebanyak 13 responden (26\%) dikarenakan responden menikah lebih dari satu kali.

c) Distribusi Responden Berdasarkan Bilas Vagina

Tabel 3. Distribusi Responden Berdasarkan Kegiatan Melakukan Bilas Vagina pada Pasien Onkology di RSUD Dr. Moewardi Surakarta Bulan Mei-Juni 2010

\begin{tabular}{|c|c|c|c|}
\hline No & Bilas vagina & Frekuensi & Persentase \\
\hline 1. & Ya & 28 & 56 \\
\hline 2. & Tidak & 22 & 44 \\
\hline & Total & 50 & 100 \\
\hline
\end{tabular}

Berdasarkan tabel 3 didapatkan hasil menunjukkan bahwa kebanyakan responden melakukan bilas vagina yaitu sebanyak 28 responden $(56 \%)$, sedangkan yang tidak melakukan bilas vagina sebanyak 22 responden (44\%), mereka membersihkan alat kelamin dengan air hangat saja.

d) Distribusi Responden Berdasarkan Kejadian Kanker Leher Rahim

Tabel 4. Distribusi Responden Berdasarkan Kejadian Kanker Leher Rahim Pada Pasien Onkology di RSUD Dr. Moewardi Surakarta bulan Mei-Juni 2010

\begin{tabular}{|c|c|c|c|}
\hline No & Kejadian Kanker Leher Rahim & Frekuensi & Persentase \\
\hline 1. & Kanker leher rahim & 19 & 38 \\
\hline \multirow[t]{2}{*}{2.} & Bukan kanker leher rahim & 38 & 62 \\
\hline & Total & 50 & 100 \\
\hline
\end{tabular}


Berdasarkan tabel 4 didapatkan hasil yang menunjukkan bahwa kebanyakan responden tidak menderita kanker leher rahim yaitu sebanyak 38 responden (62\%), sedangkan yang menderita kanker leher rahim sebanyak 19 responden (38\%).

\section{3) Analisis Bivariat}

Hubungan antara variabel bebas (seks pada usia dini, promiskuitas dan bilas vagina) dengan variabel terikat (kejadian kanker leher rahim) berdasarkan distribusi sel-sel yang ada. Uji statistik yang digunakan adalah chi square dengan tingkat kemaknaan Asyimp. sig < 0,05 dan $\mathrm{Cl}(95 \%)$ serta melihat nilai Rasio Prevalensi (RP)

a) Hubungan Aktivitas Seksual Pada Usia Dini dengan Kejadian Kanker Leher Rahim

Tabel 5. Hubungan antara Aktivitas Seksual Pada Usia Dini dengan Kejadian Kanker Leher Rahim pada Pasien Onkology di RSUD Dr. Moewardi Surakarta bulan Mei-Juni 2010

\begin{tabular}{|c|c|c|c|c|c|c|c|c|}
\hline \multirow{3}{*}{$\begin{array}{l}\text { Seks } \\
\text { Usia } \\
\text { Dini }\end{array}$} & \multicolumn{4}{|c|}{ Kanker leher rahim } & \multirow{2}{*}{\multicolumn{2}{|c|}{ Total }} & \multirow{3}{*}{$\begin{array}{l}\text { Asymp. } \\
\text { Sig. } \\
\text { (2-sided) }\end{array}$} & \multirow{3}{*}{$\begin{array}{l}\mathrm{RP}(95 \% \\
\mathrm{Cl})\end{array}$} \\
\hline & \multicolumn{2}{|c|}{+} & \multicolumn{2}{|c|}{-} & & & & \\
\hline & $\mathrm{N}$ & $\%$ & $\mathrm{~N}$ & $\%$ & $\bar{N}$ & $\%$ & & \\
\hline $\mathrm{Ya}$ & 11 & 44 & 14 & 56 & 25 & 100 & \multirow{3}{*}{0,382} & \multirow{3}{*}{$\begin{array}{c}1,375 \\
0,668<\mathrm{RP}< \\
2,832\end{array}$} \\
\hline Tidak & 8 & 32 & 17 & 68 & 25 & 100 & & \\
\hline Total & 19 & 38 & 31 & 62 & 50 & 100 & & \\
\hline
\end{tabular}

Berdasarkan tabel 5 dapat diketahui bahwa responden yang melakukan aktivitas seksual pada usia dini dan menderita kanker leher rahim adalah sebanyak 11 responden atau 22,0\%. Hasil analisis antara aktivitas seksual pada usia dini dengan kejadian kanker leher rahim menunjukkan bahwa besar Asymp. Sig $=0,382$, artinya secara statistik tidak ada hubungan yang bermakna antara aktivitas seksual pada usia dini dengan kejadian kanker leher rahim pada pasien onkology di RSUD Dr. Moewardi $(p>0,05)$, $(95 \% \mathrm{Cl} 0,668<R P<2,832)$.

\section{b) Hubungan Antara Promiskuitas dengan Kejadian Kanker Leher} Rahim

Tabel 6. Hubungan antara Promiskuitas dengan Kejadian Kanker Leher Rahim pada Pasien Onkology di RSUD Dr. Moewardi Surakarta Bulan Mei-Juni 2010

\begin{tabular}{|c|c|c|c|c|c|c|c|c|}
\hline \multirow{3}{*}{$\begin{array}{l}\text { Promis } \\
\text {-kuitas }\end{array}$} & \multicolumn{4}{|c|}{ Kanker leher rahim } & \multicolumn{2}{|c|}{ Total } & \multirow{3}{*}{$\begin{array}{l}\text { Asymp. } \\
\text { Sig. } \\
\text { (2-sided) }\end{array}$} & \multirow{3}{*}{$\begin{array}{c}\mathrm{RP} \\
(95 \% \mathrm{Cl})\end{array}$} \\
\hline & \multicolumn{2}{|c|}{+} & \multicolumn{2}{|c|}{ - } & & & & \\
\hline & $\mathrm{N}$ & $\%$ & $\mathrm{~N}$ & $\%$ & $\mathrm{~N}$ & $\%$ & & \\
\hline $\mathrm{Ya}$ & 6 & 46,2 & 7 & 53,8 & 13 & $\begin{array}{c}10 \\
0\end{array}$ & & $\begin{array}{c}1,314 \\
0,632<\mathrm{RP}<\end{array}$ \\
\hline Tidak & $\overline{13}$ & 35,1 & 24 & 64,9 & 37 & $\begin{array}{c}10 \\
0\end{array}$ & 0,481 & 2,732 \\
\hline Total & 19 & 38,0 & 31 & 62,0 & 50 & $\begin{array}{c}10 \\
0\end{array}$ & & \\
\hline
\end{tabular}


Hasil analisis pada tabel 6 dapat diketahui bahwa responden dengan promiskuitas dan menderita kanker leher rahim adalah sebanyak 6 responden atau 12,0\%. Hasil analisa antara promiskuitas dengan kejadian kanker leher rahim menunjukkan besar RR adalah 1,314. Namun secara statistik tidak ada hubungan yang bermakna $(p>0,05)$ antara promiskuitas dengan kejadian kanker leher rahim pada pasien onkology di RSUD Dr. Moewardi Surakarta (Asymp.Sig=0,481). $(95 \% \mathrm{Cl} 0,632<R P<2,732)$.

\section{c) Hubungan Antara Bilas Vagina Dengan Kejadian Kanker Leher} Rahim

Tabel 9. Hubungan antara Bilas Vagina dengan Kejadian Kanker Leher Rahim pada Pasien Onkology di RSUD Dr. Moewardi Surakarta Bulan Mei-Juni 2010

\begin{tabular}{|c|c|c|c|c|c|c|c|c|}
\hline \multirow{3}{*}{$\begin{array}{c}\text { Bilas } \\
\text { Vagina }\end{array}$} & \multicolumn{4}{|c|}{ Kanker leher rahim } & \multirow{2}{*}{\multicolumn{2}{|c|}{ Total }} & \multirow{3}{*}{$\begin{array}{c}\text { Asymp. } \\
\text { Sig. } \\
\text { (2-sided) }\end{array}$} & \multirow{3}{*}{$\mathrm{RP}(95 \% \mathrm{Cl})$} \\
\hline & \multicolumn{2}{|c|}{+} & \multicolumn{2}{|c|}{-} & & & & \\
\hline & $\mathrm{N}$ & $\%$ & $\mathrm{~N}$ & $\%$ & $\mathrm{~N}$ & $\%$ & & \\
\hline Ya & 8 & $\begin{array}{r}2 \\
8,6\end{array}$ & $0^{2}$ & $\begin{array}{r}7 \\
1,4\end{array}$ & $8^{2}$ & $00^{1}$ & & 0,571 \\
\hline $\begin{array}{l}\text { Ti- } \\
\text { dak }\end{array}$ & $1^{1}$ & $0^{5}$ & $1^{1}$ & $0^{5}$ & $2^{2}$ & $00^{1}$ & 0,121 & $\begin{array}{c}0,278<\mathrm{RP} \\
<\end{array}$ \\
\hline $\begin{array}{l}\text { To- } \\
\text { tal }\end{array}$ & $9^{1}$ & $8^{3}$ & $1^{3}$ & $2^{6}$ & $0^{5}$ & $00^{1}$ & & 1,173 \\
\hline
\end{tabular}

Hasil analisis pada tabel 9 dapat diketahui bahwa responden dengan bilas vagina dan menderita kanker leher rahim adalah sebanyak 8 responden atau $16 \%$. Hasil analisis antara bilas vagina dengan kejadian kanker leher rahim menunjukkan RP adalah 0,571. Namun secara statistik tidak ada hubungan yang bermakna $(p>0,05)$ antara bilas vagina dengan kanker leher rahim pada pasien onkology di RSUD Dr. Moewardi Surakarta (Asymp.Sig=0,121). $(95 \% \mathrm{Cl} 0,278<R R<1,173)$.

\section{b. Pembahasan}

Pembahasan hasil penelitian didasarkan pada hasil analisis deskriptif, data wawancara berdasarkan kuesioner, hasil uji statistik, perhitungan Ratio Prevalensi (RP) dan tinjauan pustaka. Pembahasan dilakukan untuk menemukan alasan-alasan yang mendukung hasil penelitian.

\section{1) Aktivitas Seksual Pada Usia Dini Pada Pasien Onkology di RSUD Dr. Moewardi Surakarta}

Berdasarkan hasil penelitian sebesar $25 \%$ responden melakukan aktivitas seksual pada usia dini atau sebelum usia 20 tahun. Hubungan seksual idealnya dilakukan setelah seorang wanita benar-benar matang. Ukuran kematangan bukan hanya dilihat dari sudah menstruasi atau belum. Kematangan juga bergantung pada sel-sel mukosa yang terdapat di selaput kulit bagian dalam vagina. Umumnya sel-sel mukosa baru matang setelah wanita berusia 20 tahun ke atas.

Fakor risiko ini merupakan faktor utama, dikarenakan semakin muda seorang perempuan melakukan hubungan seks, semakin besar risikonya untuk terkena kanker leher rahim. Berdasarkan penelitian para ahli, 
perempuan yang melakukan hubungan seks pada usia kurang dari 17 tahun mempunyai risiko lebih besar daripada yang menikah pada usia lebih dari 20 tahun. Hal ini karena pada saat usia muda, sel-sel rahim masih belum matang. Sel-sel tersebut tidak rentan terhadap zat-zat kimia yang dibawa oleh sperma dan segala macam perubahannya. Jika belum matang, bisa saja ketika ada rangsangan sel yang tumbuh tidak seimbang dengan sel yang mati, dengan begitu maka kelebihan sel ini bisa berubah sifat menjadi sel kanker. ${ }^{4}$

\section{2) Promiskuitas Pada Pasien Onkology di RSUD Dr. Moewardi Surakarta}

Berdasarkan hasil penelitian sebesar $26 \%$ pasien onkology di RSUD Dr. Moewardi Surakarta melakukan aktivitas promiskuitas, karena Human Papilloma Virus yang merupakan faktor etiologi maka kanker servik mempunyai beberapa faktor risiko yang umumnya terkait dengan suatu penyakit akibat hubungan seksual. Penyimpangan pola kehidupan seksual merupakan faktor risiko yang sangat berperan.

Penyebab penyakit kanker leher rahim antara lain adanya perubahan gen, terkena mikroba, radiasi, atau pencemaran oleh bahan kimia, serta termasuk mikroba misalnya virus HPV, terutama nomor 16 dan 18. Sementara persentase akibat radiasi nilainya rendah sekali. Golongan virus DNA diduga memegang peran penting dalam terjadinya mutasi gen. Asam nukleat virus DNA tersebut dapat bersatu ke dalam gen dan DNA sel tuan rumah sehingga berperan besar dan diduga hanya sebagai kofaktor atau dapat dianggap sama dengan zat penyebab kanker kimia atau fisik. Penyebab serius lainnya adalah sperma pria. Pasalnya, bagian kepala sperma mengandung protein dasar. Apabila menyatu dengan leher rahim, protein dasar ini dapat mengakibatkan gangguan pertumbuhan sel di serviks. ${ }^{2}$

Ada bukti kuat kejadiannya mempunyai hubungan erat dengan sejumlah faktor ekstrinsik, diantaranya adalah jarang ditemukan pada perawan, insidensi lebih tinggi pada mereka yang kawin daripada yang tidak kawin, terutama pada gadis yang coitus pertama dialami pada usia amat muda. ${ }^{5}$

\section{3) Bilas Vagina Pada Pasien Onkology di RSUD Dr. Moewardi Surakarta}

Berdasarkan hasil penelitian sebesar 56\% pasien onkology di RSUD Dr. Moewardi Surakarta terbiasa melakukan bilas vagina. Responden umumnya membasuh vagina dilakukan setelah buang air kecil. Jika terlalu sering membersihkan vagina ternyata berdampak tidak baik. Terlalu sering menggunakan antiseptik untuk mencuci vagina dapat memicu kanker leher rahim, karena dapat menyebabkan iritasi di serviks. Iritasi ini akan merangsang terjadinya perubahan sel yang akhirnya berubah menjadi kanker. ${ }^{4}$

Bilas vagina sering dilakukan wanita karena mereka keliru telah percaya bahwa bilas vagina banyak memberikan manfaat kesehatan dan kesegaran bagian intim tersebut. Para wanita yang melakukan secara rutin mengatakan bahwa mereka melakukannya untuk tujuan: membersihkan vagina, bilas sisa-sisa darah setelah periode menstruasi atau datang bulan, dapat menghilangkan bau tak sedap pada daerah intim, menghindari infeksi menular seksual (IMS), salah satu cara untuk mencegah kehamilan. Kebanyakan kasus lingkungan asam $\mathrm{pH}$ vagina dapat "membersihkan" vagina secara alami. Jika ada bau yang kuat atau iritasi biasanya berarti ada sesuatu yang salah. Bilas vagina dapat meningkatkan kemungkinan infeksi pada vagina karena nozzle pada kemasan tidak steril. Satu-satunya 
alasan harus melakukan bilas vagina adalah ketika dokter menyarankan untuk melakukanya dengan alasan yang jelas. Kebanyakan dokter mengatakan lebih baik membiarkan vagina membersihkan dirinya sendiri. vagina membersihkan dirinya sendiri secara alami dengan membuat lendir. Lendir vagina akan menyapu darah sisa menstruasi, sperma, dan cairan vagina yang tersisa. Cara membersihkan vagina cukup dengan membasuh secara teratur dengan air hangat dan sabun ringan dengan $\mathrm{pH}$ netral saat mandi. ${ }^{6}$

\section{4) Responden yang Menderita Kanker Leher Rahim}

Berdasarkan hasil penelitian diperoleh sebesar 38\% responden dinyatakan positif menderita kanker leher rahim dalam berbagai stadium. Responden kebanyakan tidak menderita kanker leher rahim. Penurunan mortalitas kanker mulut rahim di negara berkembang atau maju tidak terlepas dari usaha pencegahan sekunder, terutama dengan tes Pap. Meskipun sukses, tes Pap mempunyai keterbatasan yaitu dari studi meta analisis tes Pap mempunyai sensitivitas untuk mendeteksi NIS dan kanker serviks invasive sebesar $51 \%$ dan spesifisitas $98 \%$. Negatif palsu yang besar ini 1/3 karena kesalahan interpretasi dan 2/3 karena kesalahan sampel dan koleksi slide yang buruk. Metode skrining sampai saat ini umumnya masih menggunakan Pap Smear. Gabungan Pap Smear, kolposkopi dan biopsi merupakan paket diagnosis yang baik digunakan untuk pelayanan. Sensitivitas Pap Smear bila digunakan setiap tahun mencapai $90 \%$, setiap 2 tahun $87 \%$, setiap 3 tahun $78 \%$ dan bila setiap 5 tahun mencapai $68 \%{ }^{1}$

\section{a) Hubungan Antara Aktivitas Seksual Pada Usia Dini dengan Kejadian Kanker Leher Rahim Pada Pasien Onkology di RSUD Dr. Moewardi Surakarta}

Berdasarkan hasil penelitian sebesar $22 \%$ pasien onkology di RSUD Dr. Moewardi Surakarta yang melakukan aktivitas seksual pada usia dini dan menderita kanker leher rahim. Melalui analisis tabel $2 \times 2$ diketahui RP sebesar 1,375 pada $95 \% \mathrm{Cl}=0,668<\mathrm{RP}<2,832$ dan $\mathrm{p}=0,382$, artinya bahwa tidak ada hubungan yang bermakna secara statistik antara aktivitas seksual pada usia dini dengan kejadian kanker leher rahim. Hal tersebut dapat dikarenakan kanker leher rahim dapat dicegah melalui deteksi dini dengan pemeriksaan Pap Smear atau IVA Test, maka dari itu penting bagi wanita yang telah aktif secara seksual untuk melakukan tes tersebut. Pemeriksaan panggul setiap tahun (termasuk Pap Smear) harus dimulai ketika seorang wanita mulai aktif melakukan hubungan seksual atau pada usia 20 tahun. Setiap hasil yang abnormal harus diikuti dengan pemeriksaan kolposkopi dan biopsi. Beberapa peneliti telah membuktikan bahwa vitamin A berperan dalam menghentikan atau mencegah perubahan keganasan pada sel-sel, seperti yang terjadi pada permukaan serviks. ${ }^{7}$

$\mathrm{Hal}$ ini tidak sesuai dengan penelitian Setyarini $(2009)^{8}$ bahwa ada hubungan usia pertama kali menikah responden dengan kejadian kaner leher rahim dengan $\mathrm{P}=0,023$ dimana nilai $\alpha$ adalah lebih besar. Juga tidak sesuai dengan hasil penelitian Joeharno $(2008)^{9}$ bahwa umur perkawinan merupakan faktor risiko terhadap kejadian kanker leher rahim dengan besar risiko 2,5 kali untuk mengalami kanker leher rahim pada perempuan yang melaksanakan perkawinan pada usia $\leq 20$ tahun dibandingkan dengan perkawinan pada usia $\geq 20$ tahun. 
b) Hubungan Antara Promiskuitas dengan Kejadian Kanker Leher Rahim Pada Pasien Onkology di RSUD Dr. Moewardi Surakarta

Diketahui bahwa responden yang melakukan aktivitas promiskuitas dan menderita kanker leher rahim adalah sebesar $46,2 \%$. Melalui analisis tabel $2 \times 2$ diketahui RP sebesar 1,314 pada $95 \% \mathrm{Cl}=$ $0,632<R P<2,732$ dan $p=0,481$, artinya bahwa tidak ada hubungan yang bermakna secara statistik antara promiskuitas dengan kejadian kanker leher rahim. Hal tersebut dapat dikarenakan penularan HPV melalui hubungan seksual dapat dicegah dengan menggunakan kondom. Hasil evaluasi Cohrane Review yang dilaporkan pada 25 Mei 2001, menyimpulkan penggunaan kondom secara konsisten mempunyai kemampuan untuk mencegah transmisi HIV dengan efektivitas $80 \%$. Evaluasi dilakukan terhadap 4.709 publikasi ilmiah mengenai efektivitas kondom. Walaupun tidak memberikan jaminan pencegahan $100 \%$, tetapi jika digunakan dengan benar maka kondom efektif untuk mencegah infeksi menular seksual (IMS) dan AIDS. ${ }^{10}$

Infeksi genital HPV biasanya ditularkan lewat hubungan seksual. Banyak sekali penelitian membuktikan bahwa penularan HPV ini disebabkan oleh hubungan seksual dan terlebih lagi bila dilakukan dengan pasangan yang berganti-ganti. Ada suatu penelitian yang mengemukakan bahwa risiko tertularnya HPV sekitar $14,3 \%$ pada wanita yang melakukan hubungan seksual dengan satu pasangan, $22,3 \%$ pada wanita yang melakukan hubungan seksual dengan dua pasangan serta $31,5 \%$ pada wanita yang melakukan hubungan seksual dengan lebih dari tiga pasangan. ${ }^{1}$

c) Hubungan Antara Bilas Vagina dengan Kejadian Kanker Leher Rahim Pada Pasien Onkology di RSUD Dr. Moewardi Surakarta

Diketahui bahwa responden yang melakukan kebiasaan bilas vagina dan menderita kanker leher rahim adalah sebesar 28,6\%. Melalui analisis tabel $2 \times 2$ diketahui RP sebesar 0,571 pada $95 \% \mathrm{Cl}=$ $0,278<R P<1,173$ dan $p=0,121$, artinya bahwa tidak ada hubungan yang bermakna secara statistik antara bilas vagina dengan kejadian kanker leher rahim. Hal tersebut dapat dikarenakan bila seseorang mempunyai daya tahan atau kekebalan tubuh yang kuat maka tubuh akan dapat melawan virus. Vagina dalam keadaan sehat memproduksi cairan yang bening, tidak berbau, tidak berwarna, dalam jumlah yang tak berlebihan dan sedikit licin. Fungsi dari cairan ini adalah untuk melindungi vagina dari gesekan antara dinding vagina pada saat beraktivitas, misalnya berjalan atau berhubungan seksual. Selain itu ternyata ada juga mahluk hidup yang tinggal dalam vagina, yang juga sangat dibutuhkan oleh vagina yaitu bakteri Dorderleins. Keadaan sehat dan normal jumlah bakteri ini dominan dalam vagina, berfungsi menjaga keseimbangan ekosistem vagina. Pada beberapa kondisi hormonal tertentu keseimbangan ekosistem ini akan terganggu ,misalnya pada'saat stress, kelelahan, menjelang dan setelah haid, diabetes melitus, hamil, terangsang, mencapai orgasme, mengkonsumsi pil hormonal semisal pil KB. Selain hal tersebut, ekosistem vagina juga dipengaruhi oleh peran dari hormon estrogen dan bakteri Lactobacillus, bakteri ini juga dikenal sebagai bakteri baik bagi vagina. Fungsi hormon estrogen ini adalah untuk menentukan kadar zat gula sebagai simpanan energi dalam tubuh dalam bentuk glikogen. Glikogen ini juga merupakan makanan dari bakteri Lactobacilus yang akan dimetabolisme utk kehidupan bakteri. Sebagai sisa dari proses metabolisme ini adalah 
asam lactat yang dapat mempengaruhi keasaman dalam vagina $(\mathrm{pH}$ vagina) yaitu mencapai kisaran nilai 3,8 - 4,2, dengan tingkat keasaman vagina seperti ini maka bakteri jahat (patogen) akan mati tetapi bakteri Lactobacillus akan subur (bakteri baik). Tingkat keasaman seperti ini menyebabkab vagina akan aman dari serangan bakteri jahat. $^{6}$

Dilaporkan pada perempuan yang melakukan bilas vagina paling sedikit 1 kali seminggu mempunyai risiko 2 kali menderita kehamilan di luar kandungan. Risiko tersebut akan meningkat menjadi 4,4 kali jika menggunakan bahan bilas vagina komersial. Tidak itu saja, tindakan bilas vagina juga akan mendorong mikroorganisme di vagina dan leher rahim masuk kedalam rongga rahim (kavum uteri), saluran telur (tuba falopii) dan indung telur (ovarium). Penelitian di Amerika membuktikan bahwa perempuan yang secara rutin melakukan bilas vagina lebih besar kemungkinan terkena masalah kesehatan dari pada perempuan yang tidak rutin melakukannya. Dilaporkan bahwa perempuan yang melakukan bilas vagina 3 kali atau lebih dalam sebulan akan akan mempunyai risiko 3,6 kali menderita penyakit radang panggul dibandingkan dengan mereka yang melakukannya kurang dari 1 kali sebulan, sedangkan hubungan antara tindakan bilas vagina dengan penyakit akibat hubungan seksual, dilaporkan perempuan yang selalu menggunakan rebusan daun sirih atau bahan komesial akan mempunyai risiko jauh lebih besar menderita penyakit-penyakit hubungan seksual. ${ }^{3}$

\section{SIMPULAN DAN SARAN}

\section{a. Simpulan}

Berdasarkan hasil analisis dan pembahasan dapat disimpulkan sebagai berikut:

1) Tidak terdapat hubungan yang signifikan antara aktivitas seksual pertama pada usia dini dan kejadian kanker leher rahim di RSUD Dr. Moewardi Surakarta. Namun demikian aktivitas seksual pertama kali pada usia dini memiliki keterpaparan dapat terkena kanker leher rahim sebesar 1,375 kali dibandingkan dengan yang tidak melakukan aktivitas seksual pertama kali pada usia dini.

2) Tidak terdapat hubungan yang signifikan antara promiskuitas dan kejadian kanker leher rahim di RSUD Dr. Moewardi Surakarta. Namun demikian promiskuitas memiliki keterpaparan dapat terkena kanker leher rahim sebesar 1,314 kali dibandingkan dengan yang tidak promiskuitas.

3) Tidak terdapat hubungan yang signifikan antara bilas vagina dengan kejadian kanker leher rahim di RSUD Dr. Moewardi Surakarta. Namun demikian melakukan tindakan bilas vagina memiliki keterpaparan dapat terkena kanker leher rahim sebesar 0,571 kali dibandingkan yang tidak melakukan bilas vagina.

\section{b.Saran}

1) Bagi RSUD Dr. Moewardi Surakarta

Diharapkan pihak RSUD Dr. Moewardi dapat memberikan penyuluhan kepada masyarakat umumnya dan pasien yang datang khususnya agar mereka mengetahui faktor-faktor risiko yang dapat menyebabkan terkena kanker leher rahim.

2) Bagi Fakultas Kesehatan Masyarakat UAD 
Diharapkan bagi civitas akademika untuk dapat berperan dalam upaya pencegahan kanker leher rahim baik melalui penemuan dalam cara pencegahan maupun melalui kampanye kepada masyarakat luas. Hal tersebut untuk membantu kaum wanita yang sangat membutuhkan informasi pencegahan terutama bagi mereka yang jauh dari jangkauan informasi.

3) Bagi Peneliti Lain

Diharapkan kepada peneliti yang hendak melakukan penelitian tentang kanker leher rahim dapat menggali lebih banyak dan mendalam lagi mengenai faktor-faktor yang dapat menyebabkan seorang wanita terkena kanker leher rahim antara lain: usia lebih dari 35 tahun, merokok, paritas, riwayat penyakit kelamin, penggunaan kontrasepsi oral dalam jangka waktu lama. Dikarenakan penyakit kanker leher rahim sebenarnya dapat dicegah dan diharapkan dapat dideteksi sejak dini agar tidak terlambat dalam pengobatan.

\section{DAFTAR PUSTAKA}

1. Rasjidi, I., Sulistiyanto, H., Vaksin Human Papilloma Virus dan Eradikasi Kanker Mulut Rahim, CV, Sagung Seto, Jakarta. 2007

2. Diananda, R, Mengenal Seluk Beluk Kanker dan Simplisia Antikanker, Katahati, Yogyakarta. 2007

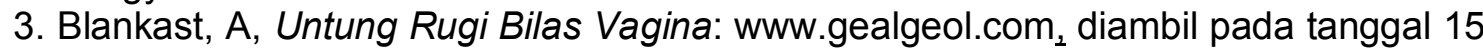
Februari 2010. Yogyakarta. 2008

4. Sukaca, B. E., Cara Cerdas Menghadapi Kanker Serviks, Genius Publisher, Yogyakarta. 2009

5. Wiknjosastro, H., Ilmu Kandungan, Edisi Kedua, Yayasan Bina Pustaka Sarwono Prawirohardjo, Jakarta. 2000

6. Arie, Bilas Vagina Sehatkah: www.nusahealth.com ${ }_{2}$ diambil pada tanggal 24 Agustus 2010, Yogyakarta. 2010

7. Amalia, L., Mengobati Kanker Serviks Dan 32 Jenis Kanker Lainnya, Landscape, Yogyakarta. 2009

8. Setyarini, E., Faktor-Faktor yang Berhubungan dengan Kejadian Kanker Leher Rahim Di RSUD Dr. Moewardi Surakarta, Skripsi, Fakultas Ilmu Kesehatan, Universitas Muhammadiyah Surakarta. 2009

9. Joeharno, M., Analisis Faktor Risisko Kejadian Kanker Serviks, Tesis, Pascasarjana, Universitas Hasanudin, Makasar. 2008

10. Sasongko, A., Kondom Masih Menjadi Alternatif Pencegahan HIVIAIDS: www.medicastrore.com,diambil pada tanggal 25 Agustus 2010, Yogyakarta. 2007 